\title{
EFFECT OF FINANCIAL LITERACY AND RISK PERCEPTION ON STUDENT INVESTMENT DECISIONS IN JAKARTA
}

\author{
Rizky Eko Harry Saputro \& Diyan Lestari \\ Manajemen, Fakultas Bisnis Institut Teknologi dan Bisnis Kalbis \\ Jalan Pulomas Selatan Kav. 22, Jakarta Timur, 13210
}

\begin{abstract}
This study aims to determine the effect of financial literacy and risk perception on student investment decisions in Jakarta. This study used a quantitative approach through questionnaires with as many as 120 respondents taken as sample which is obtained by using non-probability sampling technique and purposive sampling method. The research data is processed with SPSS, where the hypothesis is analyzed using t-test and multiple linear regression analysis. The results of this study indicate that financial literacy variable have a significant effect on investment decision, based on the t-test result which shows that $\mathrm{t}$-count is higher in comparison to $\mathrm{t}$ table $(8,433>1,98045)$. Similarly, the risk perception variable have a significant effect on investment decision, which is shown by the higher tcount compared to t-table $(2,319>1,98045)$.
\end{abstract}

Keywords: financial literacy, risk perception, investment, investment decision

\section{INTRODUCTION}

Current economic growth indicates that there is an increase in people's purchasing power, although the increase is quite low from year to year. This happens because of the increase in various factors, both government macroeconomic policies and micro activities that hastened the economic cycle in the community. Based on statistical data released by the Central Statistics Agency (2018), Indonesia's economic growth tended to be stable at around 5\% in the last three years and has charted an increase, albeit thin.

\footnotetext{
*Corresponding Author.

e-mail: rizkyekohs@gmail.com
} 
Along with the current level of public consumption, especially in big cities like Jakarta, the large number of population will have an impact on the high level of consumption. Jakarta City is the capital of Indonesia, which is also the center of the country's economy, and the city has a high population density level. Based on the Central Statistics Agency, the population in Jakarta in 2018 is 10.467 million, and it is projected that in 2019 this number will reach 10.557 million. Jakarta itself is a place for people to work and study. Therefore, in Jakarta there are a lot of state and private universities or colleges. This indicates that there are many students who are enrolled to study at these tertiary institutions. Students at various economic levels (low end-high end), of course, will perform economic activities in order to meet their needs.

In addition to the level of consumption, another thing to consider is related to community decisions regarding saving, insurance, and investment because every activity aggregately related to household financial management will have an impact on a country's economic performance. The allocation of public income to invest is very important because investing can allocate fund or capital to obtain expected goals in the form of future profit and these investments made by the community will encourage the progress of a country.

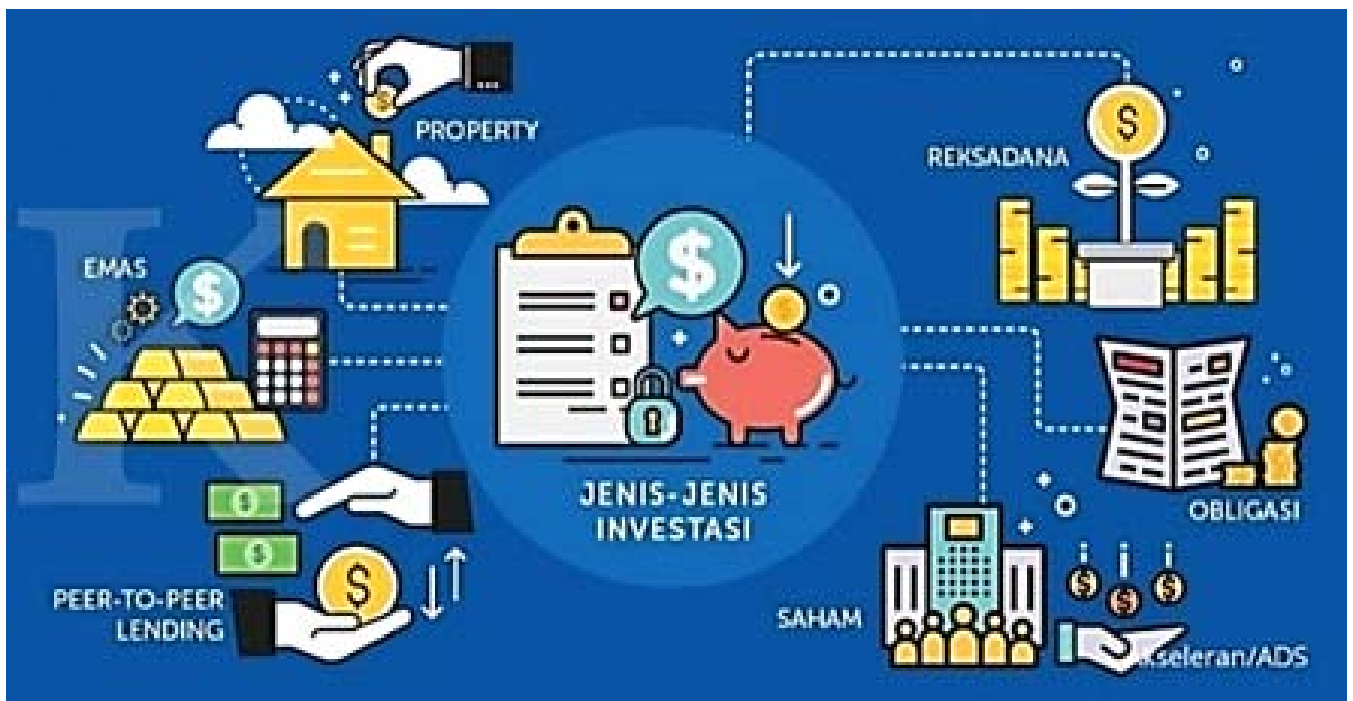

Figure 1.1 The Various Types of Investments Sumber: Kontan.co.id (2018) 
Investment is the activity of placing capital into a particular business with the purpose of obtaining additional income or profit (Wulandari \& Iramani, 2014: 57). Investment activity is a financial management activity carried out by the public in order to obtain income or return. According to Ivan Jaya (2018), the Head of Wealth Management \& Retail Digital Business of Commonwealth Bank, the interest of the Indonesian people to invest is still considered quite low. In comparison, Indonesia's investment activity is far lower than neighboring countries. At present, the number of people investing is only $0.4 \%$ of the total Indonesian population. Meanwhile, neighboring countries which are more familiar with investments reaches higher investment levels, such as Malaysia, at 57\% of the population, Thailand at 6\%, China at 9\%, and India at $4 \%$.

Figure 1.1 shows the various types of investments that can be made for someone who will place their capital or funds to obtain profit through investment, including in mutual funds, bonds, stocks, peer to peer lending, gold, and property. All of these investments have their own respective characteristics in carrying out investment activities in order to achieve the objectives.

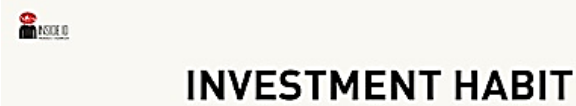

Do you have any investment currently?
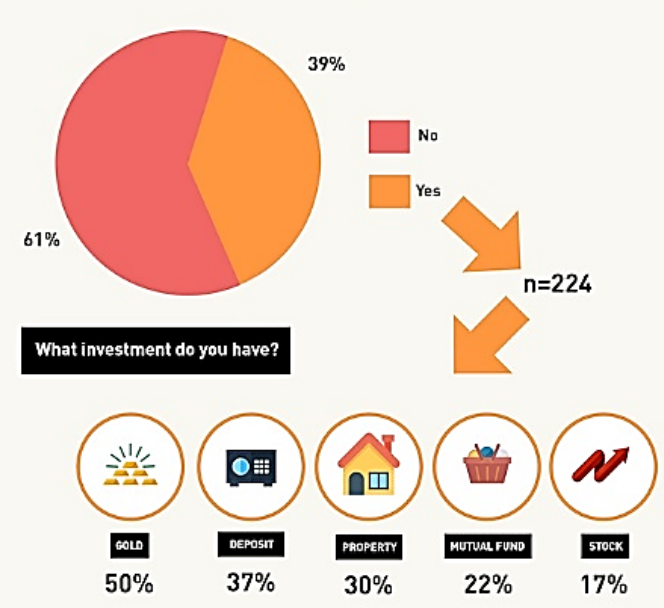

Figure 1.2 Investment Habit

Sumber: (Kontan.co.id, 2018) 
In investing, a person is faced with a decision regarding their attitude towards the investment. To achieve investment objectives and obtain optimal returns, the right investment decisions are needed to avoid problems. An investment decision is a policy or a decision taken to invest capital in one or more assets, or how a person must allocate funds into investment forms that will be able to bring benefits in the future (Wulandari \& Iramani, 2014: 57).

Indeed, people's income has been mostly used for consumption purposes. The reason is that based on Inside ID's findings, of the 600 consumers surveyed online, only $13 \%$ allocated their income to savings and investment. From this allocation, respondents set aside 79\% for savings and $21 \%$ for investment. Inside ID mentioned that the average number of investment enthusiasts rose 0.25 from the average rate in 2017. In fact, around $40 \%$ of respondents claimed to have an investment product. Regarding investment instruments chosen by the society, based on research results, gold is still the preferred choice as $50 \%$ of respondents invested in precious metals. Meanwhile, other forms of investment considered by the public are deposits (37\%), property (30\%), mutual funds (22\%), and shares $(17 \%)$ as illustrated in Figure 1.2 above.

KSEI (Kustodian Sentral Efek Indonesia) (2018) noted that young people or millennials still dominate the number of investors in the Indonesian capital market. Throughout 2018, the number of young investors aged 21-30 years formed $39.72 \%$ of the total number of investors. KSEI recorded Single Investor Identification (SID) data in December 26, 2018 and the number of investors in the Indonesian capital market reached 1.6 million. This figure increased by $44.06 \%$ compared to the number of investors in the same period in 2017 , which was 1.1 million. This indicates that students play an active role in investment activities.

When individuals plan to invest, surely it will be better if the individual has good financial knowledge or financial literacy so that his financial decisions have a clear direction. Putri \& Rahyuda (2017: 3410) explained that financial literacy is a basic need for everyone to avoid financial problems. Financial literacy becomes inseparable in an individual's life because financial literacy is something that supports financial decision-making processes, especially regarding investment. Gozali (2015: 4-5) said that financial problems can sometimes be avoided. 
However, if we hold our own financial controls, we have a greater chance of avoiding problems faster than those who are not in control of their finances. According to Yushita (2017: 13), a good understanding of financial management is a way out of various problems, including reducing poverty levels. Higher financial literacy will impact welfare.

In terms of student life, financial problems that often arise with students are that they do not have income, as some students still depend on their parents (Margaretha \& Pambudhi, 2015: 77). Sabri et al. (2008: 166) said that for most students, college period is the first time they manage their own finances without the supervision of parents. Students will face problems that may be new and be in a new environment without the supervision and support of parents. Therefore, financial knowledge or literacy is needed making a financial decision, especially regarding investments. This is certainly very helpful for students in managing their finances and adding insight in investing in the capital market or financial market.

Yushita (2017: 13) explained that the knowledge and understanding of personal finance is needed by individuals to be able to make the right decisions in finance so they can optimally use the instruments and the right financial products. Lack of financial literacy is a serious problem and a major challenge for the community, especially for students.

Table 1.1 Indonesian Financial Literacy Index (2013-2016)

\begin{tabular}{cc}
\hline \hline $\begin{array}{c}\text { Financial Literacy } \\
\text { Index 2013 }\end{array}$ & $\begin{array}{c}\text { Financial Literacy } \\
\text { Index 2016 }\end{array}$ \\
\hline $21,84 \%$ & $29,66 \%$ \\
\hline
\end{tabular}

Source: Financial Services Authority (2016)

Based on Table 1.1, which is the result of a survey conducted by the Financial Services Authority (Otoritas Jasa Keuangan - OJK) in 2016, the financial literacy index in Indonesia in 2013 was $21.84 \%$ and this number has increased to $29.66 \%$ in 2016 . This increase has not been considered as significantly high considering that Indonesian people have low financial literacy compared to other countries (Financial Services Authority, 2016). 
There are research results supporting the formation of relationships between variables that will be formed in this study. According to Dewi \& Purbawangsa (2018: 1891) who conducted a research on the effect of financial literacy, income and years of service affected investment decision behavior. The results of the study concluded that 1) Financial literacy and income have a significant positive effect on the behavior of individual investment decisions. 2) The working period does not significantly influence the behavior of individual investment decisions.

The researcher conducted pre-research observations to find out the level of student investment decisions. Respondents in this pre-research are active university students representing regions in East Jakarta, West Jakarta, North Jakarta, South Jakarta, and Central Jakarta, totaling at 30 respondents. Based on the results of the pre-research, the highest average value is that respondents or students prefer investing in the capital market compared to investing in the money market. The second highest value stated that the students prioritize return from the selected investment product. It can be concluded that respondents will prioritize the amount return they want to get. Of course, the return obtained varies depending on the selected investment product and the risk therein. Meanwhile, the lowest average value the pre-research stated that the students have not been able to predict or calculate their investment income. Thus, the knowledge in calculating or analyzing is needed for students to conduct investment activities.

The increase of individual investors is inseparable from the interference of financial service institutions and the Indonesia Stock Exchange (IDX) in collaboration with universities (Pradikasari \& Isbanah, 2018: 426). The existence of these institutions is an effort to invite the community, especially students to invest. Moreover, Jakarta is a city that has a very large number of tertiary institutions and certainly makes students a major target in increasing investment activities. It is expected that with the existence of these institutions, the community will be able to obtain and deepen financial literacy, especially for students regarding investment, specifically. The Indonesia Stock Exchange hopes to have more young student investors. According to Widjaja (2017), the Executive Director of the Indonesian Securities Companies Association, students are potential investors and thus are also targets of increasing financial literacy and inclusion, especially regarding investments. 
In making investment decisions, there are other factors that can influence a person, which is the individual internal psychological factors, one of which is perception. Perception is an individual process to obtain, organize, process, and interpret information. The same information can be perceived differently by different individuals (Sangadji \& Sopiah, 2013: 42). According to Suryani (2013: 86), perceived risk is defined as the uncertainty faced by investors when they are unable to see the possibility that will occur due to investment decisions made.

A person's perception of risk will also influence investment decision-making. Which investment is chosen and the amount of funds invested is strongly influenced by investors' tolerance or preference for risk. In other words, the attitude towards the risk faced, whether the investor likes risks (risk seekers), avoids risks (risk averter), or ignores risks (risk indifference) (Wulandari \& Iramani, 2014: 56). The behavior of investors in making decisions is influenced by the subjective attitude they have towards the risk and income of the investment itself.

Student perceptions of risk is also the cause of challenges the students face in investment decision-making. Risk perception is very important because if students have knowledge about the benefits and risks of an investment instrument, then the student will be able to perceive an investment instrument well. An individual is bound to assess an investment decision-making differently in uncertain circumstances.

The results of previous studies regarding the variables that will be formed in this study are by Pradikasari \& Isbanah (2018: 432), who conducted a research on the effects of financial literacy, illusion of control, overconfidence, risk tolerance, and risk perception on investment decisions in students in Surabaya. The results of the research conducted are concluded as: 1) Financial literacy, Illusion of control, and Risk perception does not affect investment decisions in Surabaya students. 2) Overconfidence and Risk tolerance affect investment decisions in Surabaya students. Students take irrational actions in making investment decisions (Pradikasari \& Isbanah, 2018: 426). Actions taken by students are not always in accordance with the financial theory, as students have a risk perception attitude in investment decision-making.

Based on what has been stated above, the researcher is interested in conducting a research titled: "The Effect of Financial Literacy and Risk Perception on Student Investment Decisions in Jakarta". 


\section{A. Financial Literacy}

Financial literacy is the knowledge and skills to apply understanding of concepts and risks, the ability to make effective decisions in a financial context to improve financial well-being, both individually and socially, and to participate in the community (Kemendikbud, 2017).

Financial literacy is a person's ability to know finances in general, where such knowledge includes savings, investments, debts, insurances, and other financial instruments (Fitriarianti, 2018: 4). Remund (2010: 279) explained that the concept of financial literacy has focused on five domains. These domains are:

1. Knowledge of financial concepts

2. The ability to communicate financial concepts

3. The ability to manage personal finances

4. The ability to make financial decisions

5. Confidence in financial planning

\section{B. Risk Perception}

According to Suryani (2013: 86), perceived risk is defined as the uncertainty faced by consumers when they are unable to see the likelihood that will occur as a result of a purchasing decision made. Risk perception is a perception that a person has as a consumer related to the uncertainty and unintended consequences in carrying out an activity (Syaefullah, 2013: 6).

Risk perception (risk perception) is an investor's view of the risk that will be obtained when making investment decisions (Wulandari \& Iramani, 2014: 60 ). It can be concluded that risk perception is a perception of an investor towards risks related to the uncertainty in making investment decisions.

\section{Investment Decisions}

An investment decision is a policy or a decision taken to invest capital in one or more assets or how a person must allocate funds into investment forms that will be able to bring benefit in the future (Wulandari \& Iramani, 2014: 57). According to Dewi \& Purbawangsa (2018: 1876) investment decision-making is 
the process of concluding and making decisions from several problems, making a choice between two or more investment alternatives or part of transforming inputs into outputs.

In investing, there are five factors that influence investment choices according to Yulianti \& Silvy (2013: 60-61), which are:

1. Security and risk (security in an investment means minimal risk of loss)

2. The risk factor component (component of risk factors relating to specific investments changes over time)

3. Investment income (fixed cash income)

4. Investment growth (increase in value, such as shares)

5. Liquidity (high or low)

\section{Mental Accounting Theory and Prospect Theory}

Mental accounting theory is a description of how a person performs the accounting process which can only be learned by observing someone's behavior or inferring the rules that apply in society (Silaya \& Persulessy, 2017: 59). Mental accounting focuses on how one should respond to and evaluate a situation when there are two or more possible outcomes, specifically how to combine the possibilities of these results.

Prospect theory asserts that one does not always act in accordance with financial theory standards under risk and uncertainty, where one adds uncertain psychological and behavioral factors to rational choices (Pradikasari \& Isbanah, 2018: 427). Prospect theory describes how people often make and assess decisions in risky and uncertaint conditions (Silaya \& Persulessy, 2017: 59).

\section{E. Research Model}

This study analyzes the relationship between financial literacy and risk perception on investment decisions. The analytical method used is multiple linear regression. The conceptual model can be seen in Figure 2.1. 


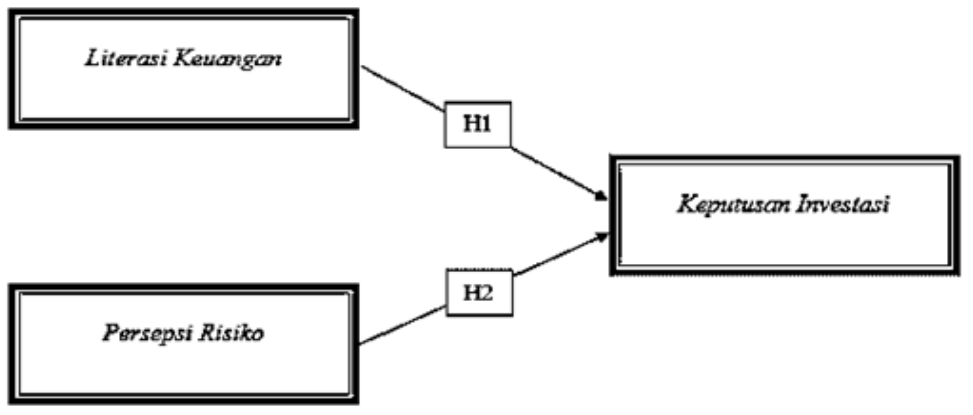

Figure 2.1 Research Conceptual Model

Financial literacy and risk perception are examined as independent variables and investment decisions are studied as dependent variables. Based on the conceptual model above, the hypotheses proposed in this study are:

H1: Financial literacy influences investment decisions

$\mathrm{H} 2$ : Risk perception influences investment decisions

\section{F. Unit of Analysis; Population and Sample}

Data sources used in this study are primary data sources, which are data collected through questionnaires. This study uses a Likert scale measurement model. According to Siregar (2014: 25), Likert scale is a scale that can be used to measure a person's attitude, opinion, and perception about an object or phenomenon. The subjects of this study were university students in East Jakarta, West Jakarta, North Jakarta, South Jakarta, and Central Jakarta. This scale is used especially if the population is large and it is impossible for the researcher to learn everything in the population. According to Malhotra (2010), the minimum sample size that can be used is the number of indicators multiplied by 5 (five). In this study there are 23 indicators $(5 \times 23)$, so the minimum sample size is 115 respondents. 120 respondent samples were obtained in this study.

Sampling uses purposive sampling technique, which is the determination of samples with certain considerations or criteria (Sugiyono, 2016: 87). The sample in this study were active college students in Jakarta and those who are registered as investors and have SID. The respondents are aged between 17-28 years old with a D3 - S2 degree, from the Faculty of Business or Economics, and have invested in stocks, mutual funds, or bonds at least once. 


\section{G. Relationship Between Variables}

\section{The Relationship Between Financial Literacy and Investment Decisions}

When an individual plans for an investment, then the individual must have good financial knowledge or financial literacy so that his financial decisions have a clear direction. Putri \& Rahyuda (2017: 3410) explained that financial literacy is a basic requirement for everyone to avoid financial problems. Financial literacy becomes inseparable in an individual's life because financial literacy is useful in making financial decisions, one of which is in making investment decisions. According to Dewi \& Purbawangsa (2018: 1885), the results of their study indicated that financial literacy has a significant positive effect on the behavior of individual investment decisions. Based on the description, the first hypothesis proposed in this study is:

H1: Financial literacy influences investment decisions

\section{The Relationship Between Risk Perception and Investment Decision}

A person's perception of risk will also influence investment decision-making. Which investment is chosen and the amount of funds invested is strongly influenced by the investors' tolerance of risk, which is the attitude towards the risk faced, whether investors like risk (risk seekers), avoid risk (risk averter), or ignore risk (risk indifference) (Wulandari \& Iramani, 2014: 56). The behavior of investors in making decisions is influenced by the subjective attitude they have towards the risk and income of the investment itself. Based on a research conducted by Wulandari \& Iramani (2014: 64), risk perception has a significant effect on investment decision-making. Based on the description, the second hypothesis proposed in this study is:

$\mathrm{H} 2$ : Risk perception influences investment decisions

\section{RESULTS AND DISCUSSION}

\section{A. Pre-Test Results}

A pre-test was conducted on some respondents who became the study sample. The number of respondents for the pre-test was 30 people. 


\section{Pre-test Validity Test}

Validity is a measurement that shows the level of accuracy (validity) of the size of an instrument against the concept being studied (Suharso, 2009: 108). Validity test is done with a significance level of $r_{\text {table }}$ of $5 \%(0.05)$. The calculated value is obtained from the correlation of each respondent's answers. Meanwhile, the $r_{\text {table }}$ value is obtained from $r_{\text {table }}$ product moment with a significance of alpha $5 \%(0.05)$, then the two-sided $r_{\text {table }}$ with a degree of freedom of $(\mathrm{df})=\mathrm{N}-2=$ 28 is obtained at 0.3610 . With the requirement if $r_{\text {count }}>r_{\text {table }}$, then the instrument is declared as valid. Meanwhile, if $r_{\text {count }}<r_{\text {table }}$, then the instrument is declared as invalid. The following table is the pre-test validity test results:

Table 3.1 Results of Pre-Test Validity Test

\begin{tabular}{llll}
\hline \hline Item & $\mathbf{R}_{\text {count }}$ & $\mathbf{R}_{\text {table }}$ & Remarks \\
\hline LK1 & 0,445 & 0,3610 & VALID \\
\hline LK2 & 0,711 & 0,3610 & VALID \\
\hline LK3 & 0,644 & 0,3610 & VALID \\
\hline LK4 & 0,707 & 0,3610 & VALID \\
\hline LK5 & 0,661 & 0,3610 & VALID \\
\hline LK6 & 0,572 & 0,3610 & VALID \\
\hline LK7 & 0,662 & 0,3610 & VALID \\
\hline LK8 & 0,707 & 0,3610 & VALID \\
\hline LK9 & 0,602 & 0,3610 & VALID \\
\hline PR1 & 0,716 & 0,3610 & VALID \\
\hline PR2 & 0,547 & 0,3610 & VALID \\
\hline PR3 & 0,821 & 0,3610 & VALID \\
\hline PR4 & 0,624 & 0,3610 & VALID \\
\hline PR5 & 0,449 & 0,3610 & VALID \\
\hline PR6 & 0,683 & 0,3610 & VALID \\
\hline KI1 & 0,822 & 0,3610 & VALID \\
\hline KI2 & 0,744 & 0,3610 & VALID \\
\hline KI3 & 0,701 & 0,3610 & VALID \\
\hline KI4 & 0,740 & 0,3610 & VALID \\
\hline KI5 & 0,763 & 0,3610 & VALID \\
\hline KI6 & 0,597 & 0,3610 & VALID \\
\hline KI7 & 0,494 & 0,3610 & VALID \\
\hline KI8 & 0,735 & 0,3610 & VALID \\
\hline & & &
\end{tabular}

Based on Table 3.1, all items of financial literacy, risk perception, and investment decision variables are valid because the value of $r_{\text {count }}>r_{\text {table }}(0.3610)$. 
Thus, it can be concluded that all instruments of statement of financial literacy, risk perception, and investment decision variables are declared as valid.

\section{Pre-test Reliability Test}

Reliability testing will be carried out using Cronbach's Alpha. The criteria for a research instrument are said to be reliable using this technique if the reliability coefficient is $\left(\mathrm{r}_{11}\right)>0.6$. The following table shows the pre-test reliability test results:

Table 3.2 Results of Pre-Test Reliability Test

\begin{tabular}{ccc}
\hline \hline & Cronbach's Alpha & N of Items \\
\hline LK & 0,814 & 9 \\
\hline PR & 0,675 & 6 \\
\hline KI & 0,851 & 8 \\
\hline
\end{tabular}

Based on Table 3.2, the Cronbach's Alpha values of financial literacy variable (LK), risk perception (PR), and investment decision (IC) are all greater than 0.6 , which are $0.814,0.675$, and 0.851 , respectively. So, it can be concluded that the instruments for the pre-test of financial literacy, risk perception, and investment decision variables are all reliable and can be trusted as a measurement tool.

\section{Pre-test Normality Test}

Normality test is performed to determine whether the population data is normally distributed or not. This study uses the Kolmogorov-Smirnov method which compares the cumulative frequency of theoretical distribution with the cumulative frequency of empirical distribution or observation (Siregar, 2015: 153). Data are stated as normally distributed if the value of significance or Asymp. Sig. (2-tailed) is more than 0.05 . The following table shows the normality test results: 
Table 3.3 Results of Normality Pre-Test

\begin{tabular}{llr}
\hline \hline \multicolumn{3}{c}{ One-Sample Kolmogorov-Smirnov Test } \\
\hline & \multicolumn{1}{c}{$\begin{array}{c}\text { Unstandardized } \\
\text { Residual }\end{array}$} \\
\hline $\mathrm{N}$ & \multicolumn{2}{c}{ Mean } \\
\hline \multirow{2}{*}{ Normal Parameters ${ }^{\mathrm{a}, \mathrm{b}}$} & Std. Dev. & 2.05160883 \\
\hline & Absolute & .158 \\
\cline { 2 - 3 } Most Extreme Differences & Positive & .091 \\
\cline { 2 - 3 } & Negative & -.158 \\
\hline Test Statistic & & .158 \\
\hline Asymp. Sig. (2-tailed) & & $.056^{\mathrm{c}}$ \\
\hline a. Test distribution is Normal. & \\
\hline b. Calculated from data. & \\
\hline c. Lilliefors Significance Correction. \\
\hline
\end{tabular}

Based on Table 3.3, the One-Sample Kolmogorov-Smirnov Test results show that the significance value (Asymp.Sig 2-tailed) is 0.056, which is greater than $0.05(0.056>0.05)$. So, it can be concluded that the instruments for the pre-test of residual value for financial literacy, risk perception, and investment decision variables are normally distributed.

\section{B. Results of Main Test}

The main tests were conducted on respondents who were research samples. The number of respondents in this study is 120 people.

\section{Validity Test}

Validity test is carried out with a significance level of $r_{\text {table }}$ of $5 \%(0.05)$ with the requirement that if $r$ count $>r_{\text {table }}$, the instrument is declared as valid. Meanwhile, if $r_{\text {count }}<r_{\text {table }}$, the instrument is declared as invalid. The value of $r$ two-sided table is $(\mathrm{df})=\mathrm{N}-2$. The number of $\mathrm{N}$ in the main test is as much as 120 , so $\mathrm{N}=120-2=118$. Obtained two-sided $\mathrm{r}_{\text {table }}$ value in the main test is at 0.1793 . The following table is the main test validity test results: 
Rizky Eko Harry Saputro, Diyan Lestarin / Effect of Financial Literacy and Risk Perception on Student Investment Decisions in Jakarta

Table 3.4 Results of Main Test Validity Test

\begin{tabular}{cccc}
\hline \hline Item & $\mathbf{r}_{\text {count }}$ & $\mathbf{r}_{\text {table }}$ & Remarks \\
\hline LK1 & 0,488 & 0,1793 & VALID \\
\hline LK2 & 0,627 & 0,1793 & VALID \\
\hline LK3 & 0,683 & 0,1793 & VALID \\
\hline LK4 & 0,710 & 0,1793 & VALID \\
\hline LK5 & 0,606 & 0,1793 & VALID \\
\hline LK6 & 0,608 & 0,1793 & VALID \\
\hline LK7 & 0,684 & 0,1793 & VALID \\
\hline LK8 & 0,725 & 0,1793 & VALID \\
\hline LK9 & 0,708 & 0,1793 & VALID \\
\hline PR1 & 0,725 & 0,1793 & VALID \\
\hline PR2 & 0,538 & 0,1793 & VALID \\
\hline PR3 & 0,723 & 0,1793 & VALID \\
\hline PR4 & 0,380 & 0,1793 & VALID \\
\hline PR5 & 0,573 & 0,1793 & VALID \\
\hline PR6 & 0,554 & 0,1793 & VALID \\
\hline KI1 & 0,728 & 0,1793 & VALID \\
\hline KI2 & 0,723 & 0,1793 & VALID \\
\hline KI3 & 0,681 & 0,1793 & VALID \\
\hline KI4 & 0,769 & 0,1793 & VALID \\
\hline KI5 & 0,708 & 0,1793 & VALID \\
\hline KI6 & 0,637 & 0,1793 & VALID \\
\hline KI7 & 0,473 & 0,1793 & VALID \\
\hline KI8 & 0,556 & 0,1793 & VALID \\
\hline & & &
\end{tabular}

Based on Table 3.4, all statement items are valid because $r_{\text {count }}>r_{\text {table }}$ $(0.1793)$. It can be concluded that all statement instruments are valid.

\section{Reliability Test}

The reliability test aims to determine the extent to which the measurement results remain consistent if measurements are made twice or more of the same symptoms using the same measuring device as well (Siregar, 2014: 55). Reliability testing will be carried out using Cronbach's Alpha. The criteria for a research instrument to be reliable is if the reliability coefficient is $\left(r_{11}\right)>0.6$. The following table shows the main test reliability test results: 
Table 3.5 Results of Main Test Reliability Test

\begin{tabular}{ccc}
\hline \hline & Cronbach's Alpha & N of Items \\
\hline LK & 0,829 & 9 \\
\hline PR & 0,604 & 6 \\
\hline KI & 0,811 & 8 \\
\hline
\end{tabular}

Based on Table 3.5, it shows that the Cronbach's Alpha value of financial literacy (LK), risk perception (PR) and investment decision (IC) variables are > 0.6 , which is $0.829 ; 0.604$, and 0.811 , respectively so it can be concluded that the instrument or questionnaire for the main test of financial literacy, risk perception, and investment decision variables are all reliable and can be trusted as a measurement tool.

\section{Classical Assumption Test}

\section{a. Normality Test}

This method of testing the normality test is done by looking at the significance value of the variable or commonly called Asymp. Sig and the significance level is 5\%. If significance or Asymp. Sig is greater than 5\%, then it is considered to be normally distributed. The following table shows the normality test results:

Table 3.6 Results of Normality Test

\begin{tabular}{llr}
\hline \multicolumn{3}{c}{ One-Sample Kolmogorov-Smirnov Test } \\
\hline \multicolumn{3}{c}{ Unstandardized Residual } \\
\hline $\mathrm{N}$ & \multicolumn{1}{c}{ Mean } & 120 \\
\hline \multirow{2}{*}{ Normal Parameters ${ }^{\mathrm{a}, \mathrm{b}}$} & Std. Deviation & 0 \\
\cline { 2 - 3 } & Absolute & .099374784 \\
\cline { 2 - 3 } Most Extreme Differences & Positive & .049 \\
\cline { 2 - 3 } & Negative \\
\hline Test Statistic & &. .043 \\
\hline Asymp. Sig. (2-tailed) & .049 \\
\hline a. Test distribution is Normal. & $.200^{\text {c,d }}$ \\
\hline b. Calculated from data. & \\
\hline c. Lilliefors Significance Correction. & \\
\hline d. This is a lower bound of the true significance. \\
\hline
\end{tabular}


Based on Table 3.6, the significance value (Asymp.Sig 2-tailed) of 0.200 is greater than $0.05(0.200>0.05)$. Thus, the residual value of the instrument or questionnaire for the main test of financial literacy, risk perception, and investment decision variable is normally distributed.

\section{b. Multicollinearity Test}

Multicollinearity test is used to test whether there is a high correlation between independent variables. Multicollinearity can be seen from the value of tolerance and its opposite, variance inflation factor (VIF). If the VIF value is less than 10 and tolerance is more than 0.10 , then the regression model is free from multicollinearity (Priyatno, 2016: 116). The following table shows the multicollinearity test results:

Table 3.7 Results of Multicollinearity Test

\begin{tabular}{|c|c|c|c|}
\hline & \multicolumn{3}{|c|}{ Coefficients $^{\mathrm{a}}$} \\
\hline & \multirow{2}{*}{${ }_{1}$ Model } & \multicolumn{2}{|c|}{ Collinearity Statistics } \\
\hline & & Tolerance & VIF \\
\hline \multirow{3}{*}{1} & (Constant) & & \\
\hline & LK & .781 & 1.280 \\
\hline & $\begin{array}{l}\mathrm{PR} \\
\end{array}$ & .781 & 1.280 \\
\hline
\end{tabular}

Based on Table 3.7, the tolerance values of both variables are more than 0.10 , which is 0.781 and the VIF values are less than 10 which is 1.280 . So, it can be concluded that there is no multicollinearity between independent variables.

\section{c. Heteroscedasticity Test}

Heteroscedasticity test is done to test the residual variance from one observation to another. Regression models that meet the requirements is where there is similarity in variance from one observation residue to another fixed observation or is also called homoscedasticity. The method used in the heteroscedasticity testing is the Glejser Test, which is done by regressing the 
residual value with each dependent variable, and the regression model residuals are said to not have heteroscedasticity problems if the significance level is $>\alpha$. In this study, $\alpha=5 \%$ (0.05) (Ghozali, 2011: 143). The following table shows the heteroscedasticity test results:

Table 3.8 Results of Heteroscedasticity Test

\begin{tabular}{c|c}
\hline \hline \multicolumn{2}{c}{ Coefficients $^{\mathbf{a}}$} \\
\hline \multicolumn{2}{c}{ Sig } \\
\hline LK & 0,058 \\
\hline PR & 0,380 \\
\hline
\end{tabular}

Based on Table 3.8, the significance value of the two independent variables is more than 0.05 , namely the financial literacy variable with a value of 0.058 and risk perception with a value of 0.380 . Thus, there is no heteroscedasticity problem in the regression model.

\section{Multiple Linear Regression Analysis}

Multiple linear regression is a statistical technique that is used to analyze the relationship between dependent variables (dependent) and independent variables (predictors) (Pramesti, 2014: 113). The purpose of multiple linear regression analysis is to determine the significance of the effect of the predictor variable (independent) on the dependent variable, so that it can contain the correct prediction. The results of multiple linear regression analysis can be seen in the following table:

Table 3.9 Results of Multiple Linear Regression Analysis

\begin{tabular}{c|c}
\hline \hline \multicolumn{2}{c}{ Coefficients $^{\mathrm{a}}$} \\
\hline \multicolumn{2}{c}{ B } \\
\hline Constant & 3,571 \\
\hline GH & 0,550 \\
\hline LK & 0,235 \\
\hline
\end{tabular}

Based on Table 3.9, the multiple linear regression equations in this study are: 


$$
\mathrm{KI}=3,571+0,550 \mathrm{LK}+0,235 \mathrm{PR}+\mathrm{e}
$$

Based on the multiple linear regression equation above, the results are:

1. The constant value obtained is 3.571 , meaning that if the financial literacy $(\mathrm{LK})$ and risk perception (PR) value is 0 , then the investment decision has a value of 3.571 .

2. The regression coefficient of financial literacy variable (LK) is 0.550 , meaning that if other independent variables are of fixed value and financial literacy (LK) has increased by 1 unit, the investment decision (IC) will increase by 0.550 or $55 \%$.

3. Regression coefficient of risk perception variable (PR) of 0.235 , meaning that if other independent variables are of fixed value and risk perception (PR) has increased by 1 unit, then investment decisions (IC) will increase by 0.235 or $23.5 \%$.

\section{5. t-Test}

The t-test aims to determine the effect of partially independent variables on the dependent variable (Priyatno, 2008: 50). The test is done by comparing $t_{\text {count }}$ with $t_{\text {table }}$ or by looking at the column of significance in each $t_{\text {count }}$. T-test results can be seen in the following table:

Table 3.10 Results of $t$-Test

\begin{tabular}{ccccc}
\hline \hline \multicolumn{1}{c}{ Variable } & Coeff & $\mathbf{t}_{\text {count }}$ & Sig. & Outcome \\
\hline Financial Literacy & 0,550 & 8,433 & 0,000 & Accepted \\
\hline Risk Perception & 0,235 & 2,319 & 0,022 & Accepted \\
\hline
\end{tabular}

Based on Table 3.10, the financial literacy variable (LK) value of $t_{\text {arithmetic }}>$ $\mathrm{t}_{\text {table }}$ is $(8.433>1.98045)$ and significance is $<0.05(0.000<0.05)$. Thus, H1 is accepted. So, financial literacy (LK) partially influences investment decisions. As for the risk perception $(\mathrm{PR}), \mathrm{t}_{\text {value }}>\mathrm{t}_{\text {table }}(2.319>1.98045)$ and the significance is $<0.05(0.022<0.05)$. Thus, $\mathrm{H} 2$ is accepted. So, risk perception partially influences investment decisions. 


\section{Coefficient of Determination $\left(\mathrm{R}^{2}\right)$}

Determination test or R square is used to find out how much influence the independent variable has on the dependent variable. According to Priyatno (2008: 79), the analysis of determination in multiple linear regression is used to determine the contribution percentage of the simultaneous influence of independent variables $\left(\mathrm{X}_{1}, \mathrm{X}_{2} \ldots\right)$ on the dependent variable. The results of the coefficient of determination $\left(\mathrm{R}^{2}\right)$ test can be seen in the following table:

Table 3.11 Results of Coefficient of Determination $\left(\mathrm{R}^{2}\right)$

\begin{tabular}{c|c|c}
\hline \hline \multicolumn{3}{c}{ Model Summary $^{\mathrm{b}}$} \\
\hline $\mathrm{R}$ & R Square & Adjusted R Square $^{\mathrm{a}}$. \\
\hline $.713^{\mathrm{a}}$ & .509 & .501 \\
\hline
\end{tabular}

Based on Table 3.11, the R Square value of 0.509 means that the percentage contribution of the influence of financial literacy and risk perception variables of investment decisions is $50.9 \%$. Adjusted R Square value of 0.501 means that if there is an addition of 1 on an independent variable, it will affect the dependent variable by $50.1 \%$. The remaining $49.9 \%$ is influenced by other variables not included in this model.

\section{Discussion}

\section{a. Discussion of Financial Literacy on Investment Decisions}

In this study, financial literacy affects investment decisions. This means that the hypothesis is accepted. Hypothesis test results ( $t$ test) showed that the value of financial literacy of 8.433 is greater than $t$ table (1.98045) and is significant. In the multiple regression analysis, financial literacy has a positive value on investment decisions. This indicates that the higher the level of student financial literacy, the better they will be in making investment decisions. In this case, financial literacy is a basic requirement for individuals or students to avoid financial problems, one of which is in making investment decisions. This study is in line with a research conducted by Dewi \& Purbawangsa (2018: 1885) and Putri \& Lestari (2019) which stated that financial literacy has a significant positive effect on the behavior of 
individual investment decisions. It can be shown that individuals who have a high level of financial literacy tend to make investment decisions easier. Investment decision-making is the process of concluding and making decisions from several choices between two or more forms of investment. Students who want to invest are expected to be able to know the benefits and risks of each investment products in order to achieve the goals they want.

\section{b. Discussion of Risk Perceptions on Investment Decisions}

In this study, risk perception influences investment decisions. This means that the hypothesis is accepted. Hypothesis test results ( $t$ test) showed that the risk perception value of 2.319 is greater than $t$ table (1.98045) and is significant. In the multiple regression analysis, risk perception has a positive value on investment decisions. This indicates that an individual's perception of risk can give rise to information regarding risks and the adjusted rate of return of the investment. Perception of risk has an important role in human behavior, especially in relation to decision-making in uncertain circumstances (Lestari, 2019). Uncertainty will be assessed and evaluated differently by different decision makers. These results are consistent with the prospect theory which asserts that a person does not always act in accordance with financial theory standards in risky and uncertain conditions, as someone adds psychological factors and erratic behavior to rational choices (Pradikasari \& Isbanah, 2018: 427).

This research is similar with a research conducted by Wulandari \& Iramani (2014: 64) which stated that risk perception has a significant effect on investment decision-making. The more investment products are perceived as relatively safe, it will encourage students to invest. While individuals or students who have low risk perceptions will be slow in making investment decisions because they think that an investment is risky.

\section{CONCLUSION}

Conclusions that can be drawn from this study are:

1. Financial literacy influences student investment decisions in Jakarta.

2. Risk perception influences student investment decisions in Jakarta. 
Based on the results of the research and the conclusions of this study, there are several managerial implications that are expected to provide benefits for several parties. First, companies or institutions engaged in financial services need to take advantage of technological developments to convey information relating to financial literacy or financial planning so that it can be easily accepted by the community, especially students.

Second, companies or institutions engaged in investment are expected to explain more broadly about investment products and the risks and returns of investment that can attract the interest of the public, especially to students in carrying out investment activities in real assets (property, gold, etc.) as well financial assets (deposits, stocks, bonds, etc.). This needs to be done in order to increase student knowledge about an investment activity.

Third, perceptions of risk are influenced by investors' tolerance or preference for risk. In this case, investors who will or want to make an investment must know in advance about the benefits and risks derived from investment products before investing. Students are advised to analyze the investment instruments first, regarding the benefits and risks that will is inherent in the investment so that it can lead to a good perception of investment decisions made.

Based on the results of the research that has been done, there are some limitations in this study, namely (1) the independent variables studied are limited to financial literacy and risk perception, (2) the non-specific research population only takes students in Jakarta without specific considerations or criteria like the level of education, income, or the field of study. Also, the sample size studied was also not too sizeable, and (3) the items in the questionnaire contained biased language, so this might confuse respondents in filling out the questionnaire.

Suggestions for further researches are intended to be the basis for future researchers who will or want to conduct any research within the same scope, including (1) the next researcher is advised to use other variables such as income, length of work, position, or level of education to determine other factors that influence investment decisions. In addition, the use of other variables is done to make it easier to find previous researches as a reference. (2) The next researcher is expected to find out the actual population size in advance and this is expected facilitate the determination of the number of research samples, and (3) it is 
Rizky Eko Harry Saputro, Diyan Lestarin / Effect of Financial Literacy and Risk Perception on Student Investment Decisions in Jakarta

advisable to make questionnaire items using words that do not confuse respondents in filling out the questionnaire.

\section{REFERENCES}

Badan Pusat Statistik. 2018. Kualitas Pertumbuhan Ekonomi Indonesia. [Online]. https://m.detik.com/news/kolom/4153925/kualitas-pertumbuhan-ekonomiindonesia (diakses pada 2 November 2018)

Dewi, I.M. \& Purbawangsa, I.B.A. 2018. "Pengaruh Literasi Keuangan, Pendapatan Serta Masa Bekerja Terhadap Perilaku Keputusan Investasi”. E-Jurnal Ekonomi dan Bisnis Universitas Udayana, 7.7: Hlm. 1867-1894.

Fitriarianti, Baiq. 2018. "Pengaruh Literasi Keuangan, Perilaku Keuangan dan Pendapatan Terhadap Keputusan Berinvestasi”. Seminar Nasional I Universitas Pamulang. Program Studi D3 Akuntasi, Hlm. 1-14.

Ghozali. 2011. Aplikasi Analisis Multivariate Dengan Program IBM SPSS 19. Semarang: Badan Penerbit Universitas Diponegoro.

Gozali, Ahmad. 2015. Habiskan Saja Gajimu! Jakarta: TransMedia.

Jaya, Ivan. 2018. Tingkat dan Minat Investasi Indonesia Memprihatinkan Karena Sangat Rendah. [Online]. http://wartakota.tribunnews.com/2018/04/17/ tingkat-dan-minat-investasi-indonesia-memrihatinkan-karena-sangat-rendah (diakses pada 14 Maret 2019).

Kemendikbud. 2017. Gerakan Literasi Nasional. [Online]. http://gln.kemdikbud. go.id/glnsite/wp-content/uploads/2017/10/literasi-FINANSIAL.pdf (diakses pada 15 Maret 2019).

Kontan.co.id. 2018. Riset Inside ID: Orang Indonesia Lebih Suka Investasi Emas Ketimbang Saham. [Online]. https://investasi.kontan.co.id/news/riset-insideid-orang-indonesia-lebih-suka-investasi-emas-ketimbang-saham (diakses pada 27 Maret 2019).

Kontan.co.id. 2018. Yuk Kenali 6 Macam Investasi yang Menjanjikan Ini. [Online]. https://ads.kontan.co.id/news/yuk-kenali-6-macam-investasi-yangmenjanjikan-ini (diakses pada 13 Maret 2019).

KSEI. 2018. Generasi Milenial Jadi Investor Terbanyak di Pasar Modal. [Online]. https://economy.okezone.com/read/2018/12/27/278/1996728/generasimilenial-jadi-investor-terbanyak-di-pasar-modal (diakses pada 31 Juli 2019) 
Lestari, D. 2019. Measuring E-commerce Adoption Behaviour Among Gen-Z in Jakarta, Indonesia. Economic Analysis and Policy, Vol. 64, Hlm. 103-115. Malhotra, N. 2010. Marketing Research: An Applied Orientation 6th Edition. New Jersey: Pearson Prentice Hall.

Margaretha, F. \& Pambudhi, R.A. 2015. "Tingkat Literasi Keuangan Pada Mahasiswa S-1 Fakultas Ekonomi”. JMK, Vol. 17(1): Hlm. 76-85.

Otoritas Jasa Keuangan. 2016. Survei Nasional Literasi dan Inklusi Keuangan 2016. [Online]. https://sikapiuangmu.ojk.go.id/ (diakses pada 3 November 2018).

Pradikasari, E. \& Isbanah, Y. 2018. "Pengaruh Financial Literacy, Illusion of Control, Overconfidence, Risk Tolerance, dan Risk Perception Terhadap Keputusan Investasi pada Mahasiswa di Kota Surabaya”. Jurnal Ilmu Manajemen, Vol. 6, No. 4: Hlm. 424-434.

Pramesti, G. 2014. Kupas Tuntas Data Penelitian dengan SPSS 22. Jakarta: PT Elex Media Komputindo.

Priyatno, D. 2016. SPSS Handbook: Analisis Data, Olah Data dan Penyelesaian Kasus-Kasus Statistik. Yogyakarta: MediaKom.

Priyatno. 2008. SPSS untuk Analisis Korelasi, Regresi, dan Multivariate. Yogyakarta: Gava Media.

Putri, N.A. \& Lestari, D. 2019. Pengaruh Gaya Hidup dan Literasi Keuangan Terhadap Pengelolaan Keuangan Tenaga Kerja Muda di Jakarta. AKURASI: Jurnal Riset Akuntansi dan Keuangan, Volume 1, Issue 1, 31-42.

Putri, N.M.D.R. \& Rahyuda, H. 2017. Pengaruh Tingkat Financial Literacy dan Faktor Sosiodemografi Terhadap Perilaku Keputusan Investasi Individu”. EJurnal Ekonomi dan Bisnis Universitas Udayana, 6.9: Hlm. 3407-3434.

Remund, D.L. 2010. "Financial literacy explicated: The Case for a Clear Definition in an Increasingly Complex Economy". The Journal of Consumer Affairs, 44 (2): Hlm. 276-295.

Sabri, et al. 2008. "Financial Behavior and Problems among College Students in Malaysia: Research and Education Implication". Consumer Interests Annual, Vol. 54: Hlm. 166-170.

Sangadji, E.M. \& Sopiah. 2013. Perilaku Konsumen: Pendekatan Praktis Disertai Himpunan Jurnal Penelitian. Yogyakarta: ANDI. 
Silaya, M.A. \& Persulessy, G. 2017. "Mental Accounting dan Faktor Demografi: Fenomena Penggunaan Kartu Kredit pada Pegawai Bank Danamon Cabang Ambon”. Jurnal SOSOQ, hlm 57-67.

Siregar, S. 2014. Metode Penelitian Kuantitatif. Jakarta: Kencana.

Siregar, S. 2015. Statistik Parametrik untuk Penelitian Kuantitatif. Jakarta: Bumi Aksara.

Sugiyono. 2016. Metode Penelitian Kuantitatif, Kualitatif, dan RひD. Bandung: Alfabeta.

Suharso, Puguh. 2009. Metode Penelitian Kuantitatif untuk Bisnis: Pendekatan Filosofi dan Praktis. Jakarta: PT Indeks.

Suryani, Tatik. 2013. Perilaku Konsumen Implikasi pada Strategi Pemasaran. Yogyakarta: Graha Ilmu.

Syaefullah, H.S. 2013. "Pengaruh Persepsi Kegunaan, Persepsi Kemudahan, Persepsi Risiko dan Kepercayaan Terhadap Minat Menggunakan Internet Banking. Jurnal Ekonomi dan Bisnis, Vol. 2 (1): Hlm. 1-18.

Widjaja, L. 2017. Mahasiswa Jadi Calon Potensial Investor Pasar Modal. [Online]. https://economy.okezone.com/read/2017/02/20/278/1623234/mahasiswajadi-calon-potensial-investor-pasar-modal (diakses pada 31 Juli 2019).

Wulandari, D.A. \& Iramani, Rr. 2014. "Studi Experienced Regret, Risk Tolerance, Overconfidence dan Risk Perception Pada Pengambilan Keputusan Investasi Dosen Ekonomi”. Journal of Business and Banking, Volume 4, No. 1: Hlm. 55-66.

Yulianti, N. \& Silvy, M. 2013. "Sikap Pengelola Keuangan dan Perilaku Perencanaan Investasi Keluarga di Surabaya”. Journal of Business and Banking, Vol. 3, No. 1: Hlm. 57-68.

Yushita, A.N. 2017. "Pentingnya Literasi Keuangan Bagi Pengelolaan Keuangan Pribadi”. Jurnal Nominal, Vol. 6 (1): Hlm. 11-26. 
Review of Management and Entrepreneurship

Volume 03, Number 02, October 2019 